The aim of this paper was to assess dietary intake and characterize the sociodemographic and smoking status in a lung cancer patient group. Material and methods: The research was performed among 15 women and 29 men who carried out a questionnaire of sociodemographic status and 24-h dietary recall from the last three days before hospitalisation. Obtained results were compared with Polish RDA (Recommended Dietary Allowances) and references.

Results: Every third person of all respondents had a vocational education; a similar percentage of patients were primary educated. All subjects were current or former smokers. Intake of fat and saturated fatty acids was higher than RDA and there were found deficiencies of polyunsaturated fatty acids and carbohydrates. The average diet of men and women provides copper and zinc below the relevant RDA. Only the average mean daily supply of sodium and phosphorus in meals of patients exceeded RDA of these minerals. The mean intake of antioxidant vitamins with diets was too high while the mean amount of B group vitamins in diets was lower than RDA.

Conclusion: Incorrect dietary habits demonstrated in patients during the period before lung cancer diagnosis in combination with smoking and low education could contribute to the development of lung cancer.

Key words: lung cancer, dietary intake, fatty acids, vitamins, minerals.

\section{Assessment of dietary intake and sociodemographic status of patients with lung cancer}

\author{
Katarzyna Zabłocka ${ }^{1}$, Marcin Gołecki ${ }^{2}$, Rafał llow ${ }^{1}$, Irena Porębska², \\ Monika Kosacka², Magdalena Bzdok ${ }^{1}$, Adam Rzechonek ${ }^{3}$, \\ Aleksandra Kamińska ${ }^{3}$, Renata Jankowska², Jadwiga Biernat ${ }^{1}$
}

${ }^{1}$ Chair and Department of Food Science and Dietetics, Wroclaw Medical University 2Department and Clinic of Pulmonology and Lung Cancers, Wroclaw Medical University ${ }^{3}$ Department and Clinic of Thoracic Surgery, Wroclaw Medical University

\section{Background}

Poland is one of the countries with the highest rates of mortality and morbidity from lung cancer [1]. There were revealed many risk factors playing a key role in the development of this disease. Cigarette smoking and exposure to harmful environmental factors such as carcinogens in the workplace, radon radiation and toxic chemical substances are very important risk factors, but apart from them, imbalanced nutrition can also play a crucial role in lung cancer aetiology. Previously performed studies indicate that high-fat and high-energy diets can accelerate the risk of lung cancer development [3]. It was also claimed that supply of all food ingredients in accordance to demands of the body can reduce the likelihood of lung cancer development [4]. Everyday consumption of a variety of vegetables and fruit rich in vitamin C, carotenoids and other oxidants is very important because these biologically active substances can protect cells against the radical species from tobacco smoke [5]. Imbalanced diet can contribute to occurrence of the disease in about $10-30 \%$ of cases [2].

The relationship between the occurrence of lung cancer and the level of education or kind of work is known [6, 7]. People of worse sociodemographic status are in the group with high risk of this disease because of their lifestyle [8].

\section{Material and methods}

Fourty-four patients (15 women and 29 men) from the Department and Clinic of Pulmonology and Lung Cancers were recruited for this study between May 2007 and June 2008. Nutritional assessment and sociodemographic status characterisation were performed by experienced staff. The dietary intake of patients was assessed using dietary recall from 72 hours before the study. For clarification of the size of portion consumed in meals, "Album fotografii produktów i potraw" was used [9]. Energy value and content of protein, carbohydrates, dietary fibre, total fats, cholesterol, fatty acids, minerals and vitamins were calculated by Nutritionist IV (First Data Bank, USA), a computer program with the Polish database performed by Kunachowicz et al. [10]. The results obtained for the individuals engaged in this study were compared to recommended dietary allowances (RDA) in Poland [11]. The following recommendations for energy supply from fatty acids were adopted in this study: saturated fatty acids - $8 \%$ of energy intake, monounsaturated fatty acids (MUFA) $-15 \%$ and polyunsaturated fatty acids (PUFA) $-7 \%$. The intake of $30 \mathrm{~g}$ of dietary fibre per day was found to be recommended in this study.

We decided to use RDA and recommendations for healthy people because the dietary recall concerned the period of time before the diagnosis of lung cancer. 
Table 1. Characteristics of age and sociodemographic status of lung cancer patients

\begin{tabular}{|c|c|c|c|c|}
\hline & Sociodemographic status & $\begin{array}{c}\text { Female } \\
\begin{array}{c}n=15 \\
\%\end{array}\end{array}$ & $\begin{array}{c}\text { Male } \\
n=29 \\
\%\end{array}$ & $\begin{array}{c}\text { All } \\
n=44 \\
\%\end{array}$ \\
\hline Age & $\begin{array}{c}\text { 26-60 years old } \\
>60 \text { years old } \\
\text { mean age }\end{array}$ & $\begin{array}{l}80.0 \\
20.0 \\
54.6\end{array}$ & $\begin{array}{l}37.9 \\
62.1 \\
64.6\end{array}$ & $\begin{array}{l}52.3 \\
47.7 \\
61.2\end{array}$ \\
\hline Marital status & $\begin{array}{c}\text { single } \\
\text { divorced } \\
\text { married } \\
\text { open relationship } \\
\text { widow/widower }\end{array}$ & $\begin{array}{c}0.0 \\
6.7 \\
73.3 \\
0.0 \\
20.0\end{array}$ & $\begin{array}{c}3.4 \\
10.3 \\
69 \\
0.0 \\
17.2\end{array}$ & $\begin{array}{c}2.3 \\
9.1 \\
70.5 \\
0.0 \\
18.2\end{array}$ \\
\hline Type of family & $\begin{array}{c}\text { alone } \\
\text { alone with support } \\
\text { with husband/wife } \\
\text { with family } \\
\text { in caring institution }\end{array}$ & $\begin{array}{c}13.3 \\
6.7 \\
33.3 \\
46.7 \\
0.0\end{array}$ & $\begin{array}{c}17.2 \\
10.3 \\
37.9 \\
34.5 \\
0.0\end{array}$ & $\begin{array}{c}15.9 \\
9.1 \\
36.4 \\
38.6 \\
0.0\end{array}$ \\
\hline Education & $\begin{array}{c}\text { basic } \\
\text { vocational } \\
\text { secondary } \\
\text { licentiate } \\
\text { higher }\end{array}$ & $\begin{array}{c}33.3 \\
33.3 \\
26.7 \\
0.0 \\
6.7\end{array}$ & $\begin{array}{c}31.0 \\
34.5 \\
27.6 \\
0.0 \\
6.9\end{array}$ & $\begin{array}{l}31.8 \\
34.1 \\
27.3 \\
0.0 \\
6.8\end{array}$ \\
\hline Place of living & $\begin{array}{c}\text { village } \\
\text { small town } \\
\text { city }\end{array}$ & $\begin{array}{c}6.7 \\
80.0 \\
13.3\end{array}$ & $\begin{array}{l}34.5 \\
55.2 \\
10.3\end{array}$ & $\begin{array}{c}25 \\
63.6 \\
11.4\end{array}$ \\
\hline
\end{tabular}

We also performed sociodemographic and smoking status assessment using a questionnaire made in the Chair and Department of Food Science and Dietetics. Educational level, place of living, type of family and number of cigarettes were included in this questionnaire.

Statistical analysis was performed with Statistica 8.0. To compare female and male attitudes to cigarette smoking, $\chi^{2}$ was used. Statistical significance was accepted at $p<0.05$.

\section{Results}

Sociodemographic status of recruited lung cancer patients

The characteristics of lung cancer patients' sociodemographic status are presented in Table 1 . The mean age of all patients was 61.2 years but women were younger than men: 54.6 years vs 64.6 years. Most recruited patients $(70.5 \%)$ were married, $18.2 \%$ were widows or widowers, and a few of them were divorced or in an open relationship. There was no difference in marital status between men and women. $38.6 \%$ of all patients lived with their wife/husband, children and grandchildren. A similar percentage of the group lived only with their wife/husband. No person was living in a care institution. More than $60 \%$ of patients lived in a small town, $11.4 \%$ lived in big cities, and 25\% were rural residents. Every third person had a vocational education, a similar percentage had basic education and only $6.8 \%$ were well educated. A metaanalysis of 64 studies from the last two years performed by Sidorchuk et al. [6] indicated an inverse correlation between the level of education and the risk of lung cancer. It shows that the type of work, especially of people with lower education, can influence the likelihood of lung cancer development.
Table 2. Lung cancer patients' attitude to smoking cigarettes

\begin{tabular}{lcccc} 
Cigarette & Female & Male & All & $P$ \\
smoking & $n=15$ & $n=29$ & $n=44$ & 0.36 \\
& $\%$ & $\%$ & $\%$ & \\
\hline Smoke & 33.3 & 20.7 & 25.0 & \\
Ever smoked & 66.7 & 79.3 & 75.0 & \\
Never smoked & 0.0 & 0.0 & 0.0 &
\end{tabular}

Table 3. Numbers of cigarettes smoked per day by lung cancer patients

\begin{tabular}{|lcccc|}
\hline $\begin{array}{l}\text { No. of cigarettes } \\
\text { smoked per day }\end{array}$ & \multicolumn{2}{c}{ Female } & \multicolumn{3}{c}{ Male } \\
\hline$<5$ & 1 & 6.6 & 0 & $\%$ \\
\hline $5-20$ & 13 & 86.7 & 16 & 0.0 \\
\hline More than 20 & 1 & 6.6 & 13 & 45.2 \\
\hline
\end{tabular}

The information about smoking cigarettes is presented in Table 2 and 3. There was no difference between women and men in smoking status. All recruited people were addicted to smoking. $75 \%$ of them smoked in the past and every fourth patient still smoked. Up to $45 \%$ of men smoked more than 20 cigarettes per day, while only about $7 \%$ of women did so. The highest percentage of women smoked 5-20 cigarettes per day. Cigarette smoking is the main cause of lung cancer development but it changes nutritional habits also. A metaanalysis of studies performed in 15 countries indicated significant differences in nutritional habits between smokers and non-smokers. People addicted to smoking consume more energy, total fat, saturated fatty acids, cholesterol and alcohol than non-smokers. They also supply less dietary fibre, vitamin $C$, vitamin $E$ and $\beta$-carotene in their diet [12]. 
Table 4. Energy value and content of nutritional compounds in male $(n=29)$ and female $(n=15)$ mean daily food ration

\begin{tabular}{|c|c|c|c|c|c|c|c|c|}
\hline \multirow[t]{2}{*}{ Nutrient } & \multicolumn{2}{|c|}{ Mean } & \multicolumn{2}{|c|}{ SD } & \multicolumn{2}{|c|}{ RDA } & \multicolumn{2}{|c|}{ RDA coverage } \\
\hline & Male & Female & Male & Female & Male & Female & Male & Female \\
\hline Energy [kcal] & 1804.1 & 1717.4 & 913.6 & 1315.4 & 1955.6 & 1866.4 & $92 \%$ & $92 \%$ \\
\hline Protein [g] & 64.4 & 59.2 & 39.6 & 40.0 & 52.3 & 46.5 & $123 \%$ & $127 \%$ \\
\hline Carbohydrates [g] & 221.8 & 221.3 & 125.9 & 179.9 & 304.0 & 285.3 & $73 \%$ & $78 \%$ \\
\hline Dietary fiber [g] & 15.8 & 19.4 & 11.0 & 22.8 & 30.0 & 30.0 & $53 \%$ & $65 \%$ \\
\hline Total fat [g] & 80.3 & 74.7 & 45.1 & 61.2 & 58.9 & 59.9 & $136 \%$ & $125 \%$ \\
\hline SFA [g] & 30.3 & 28.4 & 18.3 & 19.2 & 17.4 & 16.6 & $174 \%$ & $171 \%$ \\
\hline MUFA [g] & 31.3 & 30.3 & 18.5 & 29.4 & 32.6 & 31.1 & $96 \%$ & $97 \%$ \\
\hline PUFA [g] & 12.6 & 9.8 & 9.4 & 9.2 & 15.2 & 14.5 & $83 \%$ & $67 \%$ \\
\hline Cholesterol [mg] & 288.5 & 306.4 & 375.5 & 260.8 & 300.0 & 300.0 & $96 \%$ & $102 \%$ \\
\hline $\mathrm{K}[\mathrm{mg}]$ & 3115.3 & 3154.6 & 1528.7 & 2060.6 & 3500.0 & 3500.0 & $89 \%$ & $90 \%$ \\
\hline $\mathrm{Na}[\mathrm{mg}]$ & 1951.8 & 1664.9 & 1523.0 & 1178.5 & 575.0 & 575.0 & $339 \%$ & $290 \%$ \\
\hline $\mathrm{P}[\mathrm{mg}]$ & 998.3 & 1038.41 & 653.4 & 764.4 & 650.0 & 673.1 & $154 \%$ & $154 \%$ \\
\hline $\mathrm{Ca}[\mathrm{mg}]$ & 639.6 & 809.7 & 385.4 & 561.5 & 800.0 & 846.2 & $80 \%$ & $96 \%$ \\
\hline $\mathrm{Mg}[\mathrm{mg}]$ & 239.0 & 279.7 & 131.1 & 271.8 & 350.0 & 260 & $68 \%$ & $108 \%$ \\
\hline $\mathrm{Fe}[\mathrm{mg}]$ & 13.3 & 9.9 & 19.0 & 6.3 & 11.0 & 13.5 & $121 \%$ & $73 \%$ \\
\hline $\mathrm{Zn}[\mathrm{mg}]$ & 9.4 & 9.1 & 6.6 & 7.1 & 14.0 & 10.0 & $67 \%$ & $91 \%$ \\
\hline $\mathrm{Cu}[\mathrm{mg}]$ & 1.1 & 1.1 & 0.9 & 1.0 & 2.0 & 2.0 & $54 \%$ & $55 \%$ \\
\hline Vitamin A [ $\mu g]$ & 2893.1 & 1504.1 & 11121.9 & 2998.3 & 700.0 & 600.0 & $413 \%$ & $251 \%$ \\
\hline Vitamin E [mg] & 9.2 & 10.7 & 7.9 & 15.1 & 8.0 & 8.0 & $114 \%$ & $134 \%$ \\
\hline Vitamin $B_{1}[\mathrm{mg}]$ & 1.1 & 1.3 & 0.8 & 1.2 & 1.4 & 1.4 & $80 \%$ & $87 \%$ \\
\hline Vitamin $B_{2}[\mathrm{mg}]$ & 1.8 & 1.4 & 2.8 & 1.0 & 2.1 & 1.5 & $84 \%$ & $97 \%$ \\
\hline Vitamin B3 [mg] & 17.6 & 13.4 & 17.3 & 8.5 & 18.4 & 16.8 & $95 \%$ & $80 \%$ \\
\hline Vitamin $B_{6}[\mathrm{mg}]$ & 1.5 & 1.5 & 0.9 & 1.1 & 2.1 & 1.7 & $73 \%$ & $91 \%$ \\
\hline Vitamin C [mg] & 68.4 & 116.2 & 54.1 & 161.6 & 60.0 & 60.0 & $114 \%$ & $194 \%$ \\
\hline
\end{tabular}

\section{Nutritional assessment of recruited patients in period before lung cancer diagnosis}

Energy value and mean content of nutrients in daily food ration of men and women are presented in Table 4. The energy supply was almost equal to the recommended dietary allowance (RDA) for men and women. Females and males consumed on average $92 \%$ of proper amounts of energy, but individually only $8 \%$ of women and a similar percentage of men covered the energy needs properly. Almost every fourth man provided about $75-90 \%$ of energy RDA. A similar percentage of men supplied about $50-75 \%$ of energy RDA but every sixth male daily food ration provided only about $25-50 \%$ of energy RDA. In the female group two thirds of them provided less than $75 \%$ RDA of energy. The high percentage of patients who did not cover energy needs could result from loss of appetite caused by cigarette smoking and bad nutritional habits or could be a symptom of developing cancer [13].

The assessment of the structure of energy supply by macronutrients indicated that the average daily food ration contained $14 \%$ of energy from protein and it was correct. Carbohydrates provided $48 \%$ of energy and total fat covered $38 \%$ of daily energy consumption. Imbalanced contribution of macronutrients to energy coverage resulting from high intake of fat is a well-known factor of lung cancer [14].

In this study it was found that average content of protein in the daily food ration did not meet RDA. Only about every six recruited patients consumed proper amounts of this nutrient. The results indicate that patients supplied carbohydrates in their daily food ration below the recommendation (female - 78\%, male - 73\% RDA).

There was also low consumption of dietary fibre. In the average daily food ration the content of dietary fibre did not meet RDA. Females consumed $65 \%$ of RDA of this food ingredient and males consumed only about $50 \%$. Only $7 \%$ of all male patients consumed dietary fibre in proper amounts. It was found that insufficient intake of dietary fibre can accelerate the problems with defecation, especially during opioids intake. Those drugs are very often used during palliative care of terminally ill patients [15]. 


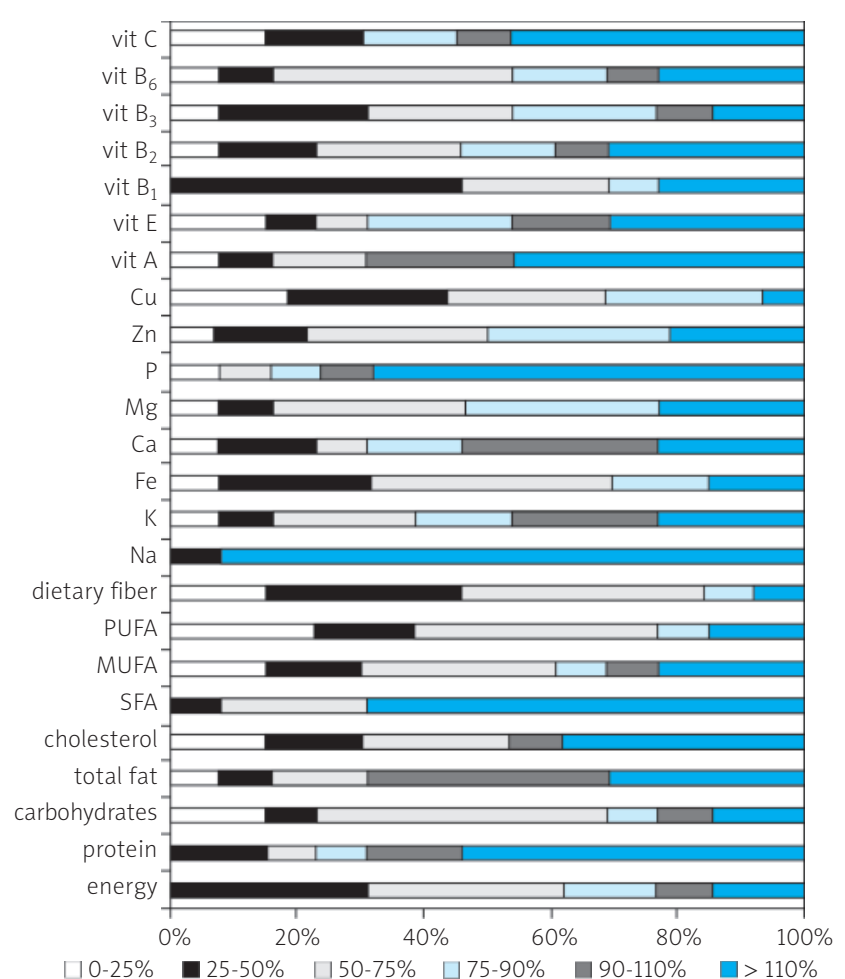

Fig. 1. The RDA coverage of food components and energy from female daily food rations $(n=15)$

In all-day meals dietary fat intake was also exceeded. Females and males consumed respectively 25\% and 36\% more of this nutrient than RDA. About $40 \%$ of females and only $7 \%$ of males ate total dietary fat in proper amounts.

In this study it was found that cancer patients consumed high amounts of saturated fatty acids (SFA). Average daily intake of that nutrient by recruited women and men was about $170 \%$ RDA. Only about $14 \%$ of males ate saturated fatty acids in proper amounts. Meat, its preparations and high-fat dairy products are rich sources of SFA. The excessive consumption of animal products causes a high percentage of energy from SFA and it can influence cancer development, including lung cancer. Studies performed by Lam et al. [16] indicated a positive correlation between meat consumption and risk of lung cancer.

In contrast to high intake of SFA, the consumption of polyunsaturated fatty acids (PUFA) was below the requirements. In the daily food ration every third person provided PUFA $50-75 \%$ RDA and $15 \%$ of female and male patients met 25-50\% RDA of these fatty acids. Insufficient intake of n-3PUFA is unsatisfying and can increase the risk of lung cancer development. n-3-PUFA have an anti-inflammatory effect and decrease the synthesis of prostaglandin E2. These fatty acids can also inhibit the expression of oncogenes coding transcription factors: AP1 transcription factor or Ras protein [17].

In this study we recorded the adequate intake of monounsaturated fatty acids (MUFA). The mean RDA coverage for MUFA in females was $97 \%$ of RDA and in males $96 \%$ of RDA. Simultaneously we found that only $14 \%$ of male and $8 \%$ of female patients consumed MUFA in adequate

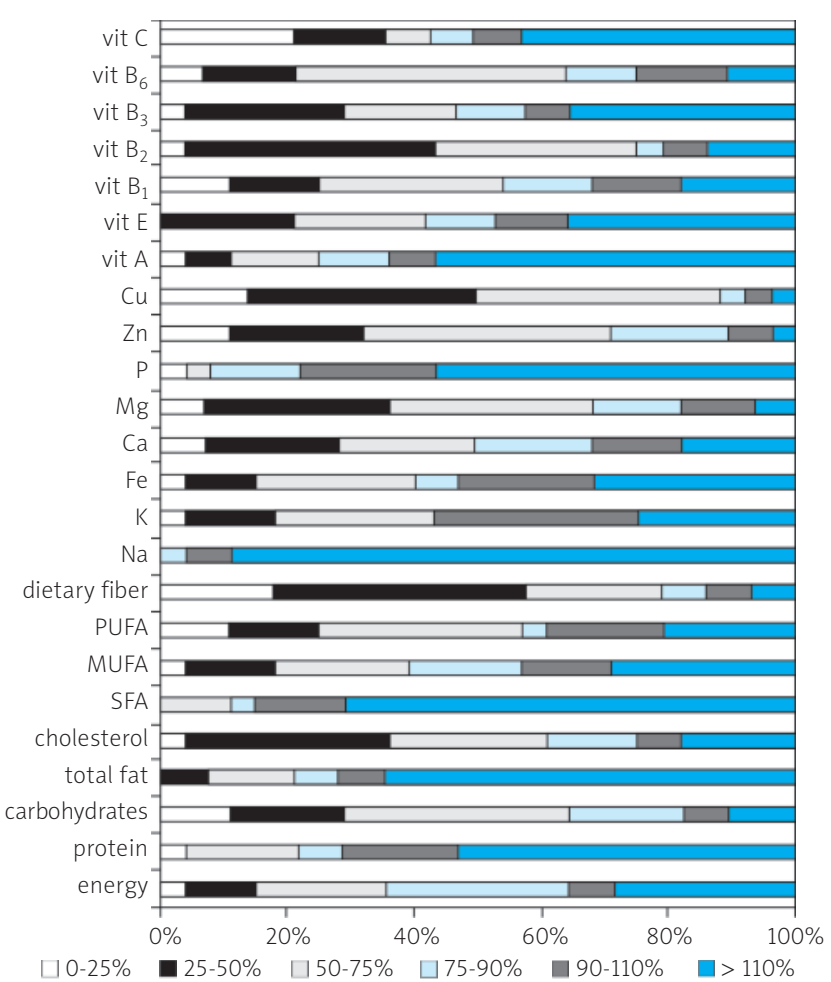

Fig. 2. RDA coverage of food components and energy from male daily food rations $(n=29)$

amounts and every fourth patient consumed excessive amounts of MUFA. The rest of the respondents ate these nutrients below the recommendation. The proper supply of MUFA appears to be relevant in protecting against lung cancer development. Fortes et al. [18] assessed the impact of a Mediterranean diet on the risk of lung cancer and indicated that high supply of dietary MUFA from olive oil is a positive dietary factor protecting against lung cancer.

The mean cholesterol intake was similar in the female and male group. It was found that $53 \%$ of females consumed less than $255 \mathrm{mg}$ of cholesterol. The proper cholesterol consumption, less than $300 \mathrm{mg}$ per day, is desirable because it reduces the probability of lung cancer development. It is expected that high amounts of dietary cholesterol in the daily food ration may increase the risk of lung cancer, but Smith-Warner et al. [19] found in a prospective study that there was no significant correlation between high consumption of cholesterol and lung cancer risk.

The assessment of mineral contents in the daily food ration of recruited patients indicated differences in RDA coverage for these nutrients. There were also differences between female and male patients.

The average contents of $\mathrm{Cu}$ in male and female daily food rations met about $55 \%$ of the estimated RDA. The insufficient intake of this mineral results in weaker integrity of DNA and induction of early stages of cancerogenesis. Cu is a cofactor for enzymes including Cu-Zn-superoxide dismutase and DNA repair proteins, which can protect cells against reactive oxygen species and DNA damage, especially in current smokers [20]. 
Insufficient average intake of Fe was observed only in female patients. The average female daily food rations provided Fe below RDA (73\%). Males consumed excessive amounts of this mineral. The average recorded amounts of Fe in male daily food rations reached $121 \%$ of RDA. Only every fifth male consumed appropriate quantities of this element. As was found in a prospective, cohort study, the excessive amounts of dietary haem iron with intensive intake of vitamin C (more than $500 \mathrm{mg} /$ day) can be a predictive factor for lung cancer development in relation to increased prooxidative processes [21].

$\mathrm{Mg}$ and $\mathrm{Zn}$ deficiency were observed in male daily food rations. They provided these nutrients in $68 \%$ and $67 \%$ of the RDA, respectively. In female daily food rations no deficiencies of magnesium and zinc were observed. The average intake of these elements was in the range $90-110 \%$ of RDA but none of the surveyed women provided proper quantities of these elements. Almost $80 \%$ of females supplied less than $260 \mathrm{mg}$ of magnesium per day and about $70 \%$ of females provided insufficient amounts of zinc. Inadequate intake of dietary magnesium is very unhealthy especially during platinum analogue therapy. These cytostatics may induce hypomagnesaemia in nearly $90 \%$ of the patients because of damage of the proximal and distal tubules, resulting in nephrotoxicity [22]. Too small amounts of this mineral in the diet may intensify drug-induced hypomagnesaemia and lead to neuromuscular hyperexcitability, tachycardia, loss of appetite, vomiting, diarrhoea and weakness [23].

The intake of potassium in the mean male daily food ration was $89 \%$ of RDA. Average intake of this mineral in female daily food rations was similar and met $90 \%$ of RDA. Surveyed women provided higher amounts of calcium than men (809.7 mg vs 639.6 mg per day). Almost every third women consumed proper amounts of Ca. Men provided Ca in about $80 \%$ of RDA. The male and female mean daily food ration covered more than $150 \%$ of RDA of phosphorus. Amounts of Na were also exceeded: $290 \%$ of RDA in women and $339 \%$ of RDA in men. The incorrect supply of minerals is very disadvantageous for cancer patients during treatment because absorption in the small intestine is impaired. Many cytostatics, including cisplatin (often used in the treatment of lung cancer), induce persistent nausea and vomiting. In some cases they may last for almost a week, causing dehydration and electrolyte disturbances [24].

The average content of vitamin A, C and E in all patient daily food rations exceeded RDA for these vitamins, but the mean supply of vitamin $C$ and $E$ in male daily food rations was only slightly excessive. The average supply of vitamin $A$ in all patient diets was strongly excessive. Females consumed vitamin A in average amounts exceeding $200 \%$ of RDA but male daily food rations provided average amounts of this vitamin more than $400 \%$ of RDA. Recruited patients were current or former smokers exposed to high amounts of reactive oxygen species. These harmful compounds can be partly eliminated by dietary antioxidants such as antioxidant vitamins [25]. However, it is not allowed to complement the dietary deficiencies with supplements because excessive amounts of antioxidants can lead to greater risk of lung cancer development [26].
There was an insufficient content of thiamine in the average patient daily food ration. The mean vitamin B1 consumption in the studied cancer patient group met $87 \%$ (female) and $80 \%$ (male) of estimated RDA. There was also insufficient average intake of riboflavin and pyridoxine but only in the male daily food ration: $84 \%$ and $73 \%$ of RDA, respectively. The mean intake of thiamine and pyridoxine met RDA but niacin consumption was too low. Women consume this vitamin in amounts covering $80 \%$ of RDA. Men consumed an adequate quantity of niacin.

\section{Conclusions}

1. Incorrect contribution of macronutrients in energy coverage resulted from overconsumption of total fat and insufficient intake of carbohydrates.

2. The average daily food ration provided too high amounts of saturated fatty acids while intake of polyunsaturated fatty acids was below the dietary recommendation.

3. The average daily food ration provided too small amounts of $B$ vitamins in comparison with RDA.

4. Wrong nutritional habits connected with smoking addiction and also with low educational level are strong risk factors predisposing to the development of lung cancer.

\section{References}

1. Kosacka M, Jankowska R. Epidemiologia raka płuca. Pneumol Alergol Pol 2007; 75: 76-80.

2. Batura-Gabryel H. Sesja satelitarna - rak płuca - koniec czy poczatek możliwości diagnostyczno-terapeutycznych ? Przew Lek 2008; 1 11-4.

3. De Stefani E., Deneo-Pellegrini H., Mendilaharsu M, Carzoglio JC, Ronco A. Dietary fat and lung cancer: a case-control study in Uruguay. Cancer Causes Control 1997; 8: 913-921.

4. Brennan P, Fortes C, Butler J. A multicenter case-control study of diet and lung cancer among non-smokers. Cancer Causes Control 2000; 11: 49-58.

5. Wright ME, Park Y, Subar AF, Freedman ND, Albanes D, Hollenbeck A, Leitzman MF, Schatzkin A. Intakes of fruit, vegetables and botanical groups in relation to lung cancer risk in the NIH-AARP diet and health study. Am J Epidemiol 2008; 168: 1024-34.

6. Sidorchuk A, Agardh EE, Aremu O, Hallqvist J, Allebeck P, Moradi T. Socioeconomic differences in lung cancer incidence: a systematic review and metaanalysis. Cancer Causes Control 2009; 20: 459-471.

7. Ruano-Ravina A, Figueiras A, Barros-Dios JM. Lung cancer and related risk factors: an update of the literature. Public Health 2003; 117: 149-56.

8. Mao Y, Hu J, Ugnat AM, Semenciw R, Fincham S; Canadian Cancer Registries Epidemiology Research Group. Socioeconomic status and lung cancer risk in Canada. Int J Epidemiol 2001; 30: 809-17.

9. Szponar L, Wolnicka K, Rychlik E. Album fotografii produktów i potraw. Wydawnictwo IŻŻ, Warszawa 2000.

10. Kunachowicz H, Nadolna I, Przygoda B, Iwanow K. Tabele wartośc odżywczych produktów spożywczych. Wydawnictwo IŻż, Prace IŻż 85, Warszawa 1998

11. Ziemlański Ś. Normy żywienia człowieka. Fizjologiczne podstawy. Wydawnictwo Lekarskie PZWL, Warszawa 2001.

12. Dallongeville J, Marecaux N, Fruchart JC, Amouyel P. Cigarette smok ing is associated with unhealthy patterns of nutrient intake: a metaanalysis. J Nutr 1998; 128: 1450-7.

13. Bedor M, Alexander C, Edelman M.J. Management of common symptoms of advanced lung cancer. Curr Treat Opt Oncol 2005; 6: 61-68.

14. El-Bayoumy K, Muscat JE, Hoffmann D. Nutrition and tobacco-related cancers. In: Nutritional oncology. Heber D (ed.) Los Angeles, Elsevier 2006; 199-217 
15. Dzierżanowski T, Jarosz J. Zaparcia u chorych leczonych opioidami. Onkol Prakt Klin 2009; 5: 47-54.

16. Lam TK, Cross AJ, Consonni D, Randi G, Bagnardi V, Bertazzi PA, Caporaso NE, Sinha R, Subar AF, Landi MT. Intakes of red meat, processed meat and meat mutagens increase lung cancer risk. Cancer Res. 2009; 69: 932-939.

17. Hardman WE. (n-3) Fatty Acids and Cancer Therapy. J Nutr 2004; 134: $3427-3430$

18. Fortes C, Forastiere F, Farchi S, Mallone S, Trequattrinni T, Anatra F, Schmid G, Perucci CA. The protective effect of Mediterranean diet on lung cancer. Nutr Cancer 2003; 46[1]: 30-37.

19. Smith-Warner SA, Ritz J, Hunter DJ, et al. Dietary fat and risk of lung cancer in a pooled analysis of prospective studies cancer epidemiology. Cancer Epidemiol Biomarkers Prev.2002; 11: 987-92.

20. Mahabir S, Forman MR, Barerra SL, Dong YQ, Spitz MR, Qingyi W. Join effect of dietary trace metals and DNA repair capacity in lung cancer risk. Cancer Epidemiol Biomarkers Prev 2007; 16: 2756 62.

21. Lee DH, Jacobs DR. Interaction among heme iron, zinc and supplemental vitamin C intake on the risk of lung cancer: lowa Women's Health Study. Nutr Cancer 2005; 52: 130-7.

22. Szczylik C, Wcisło G, Bodnar L, Miedzińska-Maciejewska M. Leczenie nefroprotekcyjne $w$ trakcie chemioterapii analogami platyny u chorych nowotworowych. Współcz Onkol 2003; 7: 702-9.

23. Pietruszka B. Niedobory składników mineralnych. In: Składniki mineralne w żywieniu człowieka. Brzozowska A (ed.). Wyd. Akademii Rolniczej, Poznań 2002; 86-94.

24. Malinowska K, Modranka R, Kedziora J. Leki przeciwnowotworowe stosowane w lecznictwie oraz będące w fazie badań klinicznych. Pol Mer Lek 2007; 23: 65-169.

25. Bloomer RJ. Decreased blood antioxidant capacity and increased lipid peroxidation in young cigarette smokers compared to nonsmokers: impact of dietary intake. Nutr J 2007; 6: 1-6.

26. Goodman GE. Prevention of lung cancer. Crit Rev Oncol Hematol 2000; 33: 187-97.

\section{Address for correspondence}

\section{Katarzyna Zabłocka}

Chair and Department of Food Science and Dietetics

Wroclaw Medical University

pl. Nankiera 1

50-140 Wrocław 